\title{
Most Often, What Is Transmitted Is Transformed
}

\author{
Theodore M. Porter
}

\begin{abstract}
This short interlude prompts reflection on the transformations involved in data mobilization through a vivid discussion of the changing circumstances of the visualization of data about family histories of mental illness - and their interpretation in relation to questions around inheritability and underpinning biological causes - through graphs and tables produced between the mid-nineteenth century and the early twentieth century.
\end{abstract}

Henri Legrand du Saulle used the title phrase above to encapsulate his teacher B. A. Morel's doctrine of hereditary degeneration. Degenerative heredity was defined not by stable transmission of traits from generation to generation, but as a trajectory of decline leading often to extinction of the line (Legrand du Saulle 1873, 9). This theory was a hit with doctors, novelists, and other authorities on human heredity for about half a century. Its fall from favor cannot be attributed to any shortage of data. It was not easy, however, to reach agreement as to what the data meant. One notable collection of family records that came to be cited in support of Morel's theory had been published in 1859 by a Norwegian asylum doctor and researcher, Ludvig Dahl. His tables of mental illness were redrawn and republished half a century later by English biometricians, then relabeled as evidence of Mendelian degeneration for a German health exposition. In each case, Dahl's data was assigned new meanings. Often, when data travels, it will be transformed (Porter 2018, 131-142 and 179).

Dahl created a partly novel visual technology, the pedigree table, to convey his understanding of pathological inheritance. Although he admitted variability in the manifestation of hereditary elements for mental disease, he regarded a close resemblance between parent and child as the most compelling indication of inheritance. His book on the subject attracted immediate attention across northern Europe for its insights on the causes and transmission of mental illness. Although he wrote in a somewhat inaccessible language, Danish/Norwegian, he attracted knowledgeable commentators in French, English, and especially German. They did not need to be convinced that heredity was key to the perpetuation of insanity, and likely its most

\footnotetext{
T. M. Porter $(\bowtie)$

Department of History, University of California, Los Angeles, Los Angeles, CA, USA

e-mail: tporter@history.ucla.edu
} 
fundamental cause. Cascades of annual asylum reports from Europe and North America included lists of the "presumed causes" of illness for newly-admitted patients, and heredity was consistently at or near the top. Dahl's book was distinctive for its fine-grained studies at a local level, typically of a single parish, which he compared with numbers from the much-admired Norwegian decennial census of insanity, first taken from 1825 to 1828 , and with data from the new asylum of Gaustad in the hills above Christiania (Oslo). Records of the 1855 census gave him access to the unpublished names of individuals reported as insane, which he supplemented by surveying parishes of interest, talking with doctors, priests and families of these unfortunate souls. This information, the basis for his kinship tables, pertained specifically to the question of hereditary transmission.

Dahl, a data guy, resisted the temptations of dogmatism. Often, children had cases very similar to their parents, but not always. He had enough examples of disparate forms of illness within a single family to declare with some assurance that a hereditary Anloeg or factor could have diverse manifestations. Insanity he understood as an "acquired" condition, distinguished by its invisibility until late adolescence. Madness was easily distinguished from idiocy, or mental weakness, which was typically congenital and often appeared in association with bodily deformities, especially of the cranium. Yet he turned up many families manifesting both conditions. Idiocy, in turn, was not only linked by heredity to deaf-mutism, but often appeared alongside it in the same individual. Dahl also mentioned albinism and even leprosy, a relatively common and much-studied condition in Norway, as other afflictions that were often allied to idiocy. The proliferation of mental and physical defects seemed to be more common where there was intermarriage, especially if a hereditary factor was present in the family (Dahl 1859, 82-86). In a section on hereditary causes, Dahl printed eight pedigrees of kin groups showing a high level of inherited illness. The most extensive of these came from the parish of Kinservik on the Hardanger fjord, east of Bergen, where the inhabitants (he said) were especially attentive to the memory of their ancestry and where the priest zealously aided the research. Despite using two foldout pages, Dahl had to divide this extended family into two charts, kin groups 4 and 5 . They revealed a variety of conditions that seemed to be joined together by heredity, including deaf-mutism, epilepsy, leprosy, blindness and albinism as well as insanity and idiocy (Dahl 1859, tables 4-5 and pp. 82-86). To this extent his tables resembled those of Morel's students, but Dahl found no directional tendency. His tables also documented intermarriage of close relatives, which, he speculated, may strengthen a hereditary tendency, but he wanted more data to be confident.

A German commentator and translator expressed puzzlement that an Anlag (in German, Anlage) could be expressed in such heterogeneous forms, sometimes even without cousin marriages. Such instability of types of insanity was an old story, and not only as heredity. A patient admitted to an asylum with a diagnosis based on one set of symptoms might have to be assigned another when these manifestations changed. The boundary between madness and idiocy, in contrast, was mostly reliable, and neither of these could be confused with albinism or leprosy (von dem Busch 1861, 483-485). 


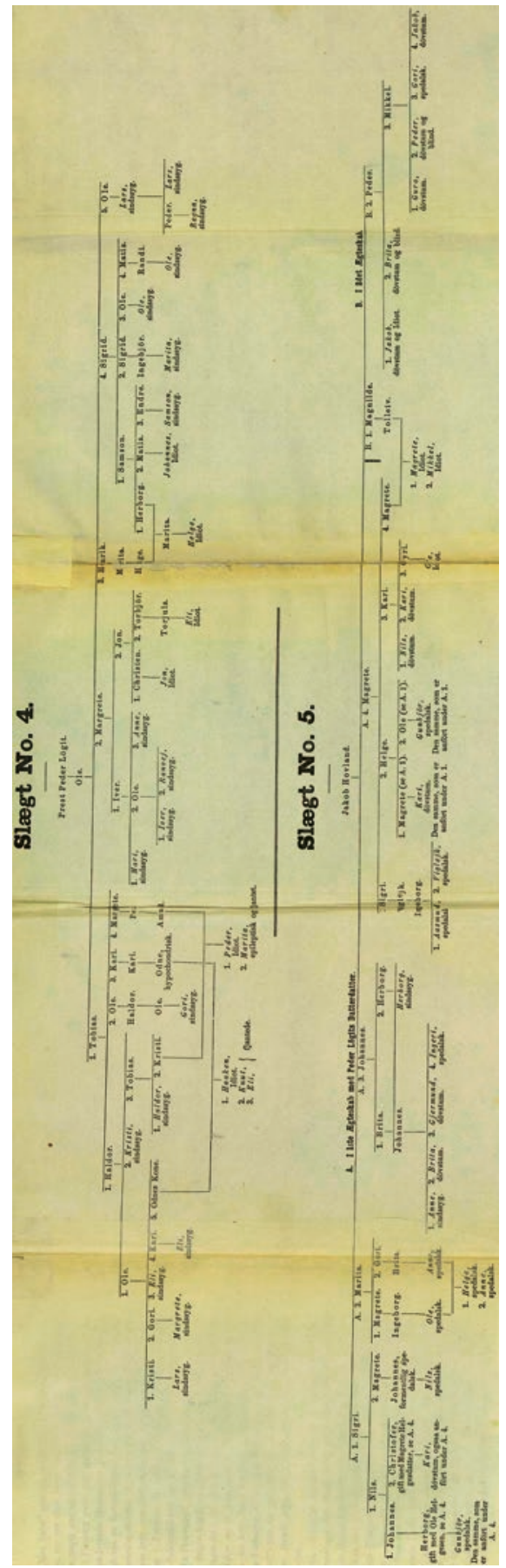


Although the work was enthusiastically received, Dahl's tables did not at first inspire imitators. In 1877, the alienist William Ireland translated a few of them into English for his book on mental defect (Ireland 1877, tables at back). But it was not until the new century that pedigree tables emerged as the indispensable tool for documenting inherited defect. The most important site of their reappearance was in the Treasury of Human Inheritance, a reference work funded by Francis Galton's Eugenics Laboratory, now under the direction Karl Pearson. The conditions documented in the initial fascicules, issued in 1909, included some anatomical abnormalities that could be described very precisely. For conditions such as mental illness and tuberculosis, however, Pearson and his coworkers preferred to speak of diathesis or constitutional susceptibility, to be identified from readily-apparent symptoms. Pearson was, after all, a statistician, not a doctor, and he was in no position impose any system of classification on such a slippery subject. Also, since these maladies were not often identified before age 20 or 25, it might well be impossible to examine ancestors beyond a single generation. Dahl had relied on written records and family recollections to compile his kinship tables.

Pearson, who stressed the painstaking labor of checking and rechecking required to assemble even one solid table of this kind, treated "Dahl's case" as having met this high standard of quality. That meant they were fit to serve as a data resource, to be compared and analyzed in pursuit of scientific conclusions on the transmission of human defects. He indicated provenance but did not call attention to singularities, and he printed tables of multiple families by multiple researchers on the same page. There is no discussion of the sites of research, and individual names were omitted. By redrawing all pedigrees in a common format, he has made them almost interchangeable. Pearson's formidable erudition included a working knowledge of the Norwegian language, which he had studied in order to read Ibsen in the original, so it is quite possible that he had a hand in the excavation of Dahl's data. Yet there is not a word here about Dahl, his site, or his methods. Pearson's ambition was to create a database of interchangeable data, one that did not require researchers to go back into the sources. He also did not use this work to defend hereditary theories or to take shots at Mendelian reductions of complex traits and behaviors. Rather, he sold his numbers as independent of all theories (Pearson 1912 [these sheets first printed 1909] plate 10; Porter 2004). 


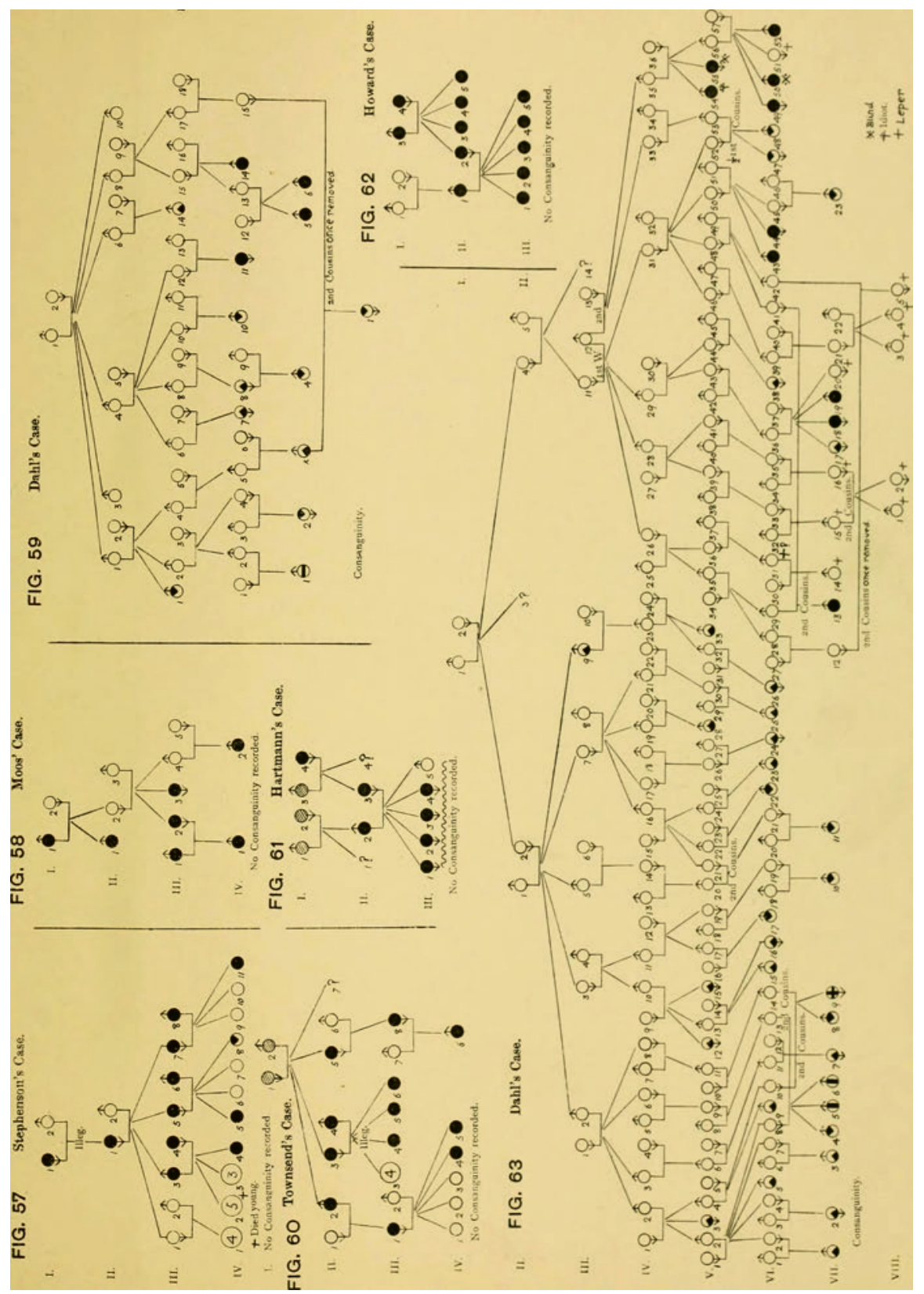


In one important sense, his effort to create a neutral database of heredity was a success. Dahl's kinship tables from Hardanger, as redrawn for the Treasury of Human Inheritance, gained instant recognition, and were featured, for example at the 1911 International Hygiene Exposition in Dresden. The German organizers and editors, Max von Grüber and Ernst Rüdin, simply reprinted the redrawn Norwegian material alongside other graphs and tables of inherited mental and nervous conditions, without even translating loose English words on these charts. As data they took Pearson's tables to be authoritative (See Nikolow 2001 on the Dresden Exhibition).

The treatment in the catalogue of Dahl's case (Fall von Dahl), however, involves some perplexing little oddities, and was anything but atheoretical. Grüber and Rüdin put to the side what Dahl had understood as the most remarkable feature of this chart, the juxtaposition of so many conditions there. The German heading for the Hardanger table reduced its multifarious defects to just one, deaf-mutism (Taubstummheit). Clearly they were looking for a striking example of Mendelian neurological inheritance. This fixation on Mendelian inheritance, nonetheless, was perfectly compatible with a relentlessly statistical presentation. And this was not all. In the course of the work, they came to be tantalized by the hopes of demonstrating Morel's mechanism of hereditary degeneration.

The printed record, consisting of two editions of the exhibition catalogue (both dated 1911), and a crowd of inconsistencies gives evidence of momentary thoughts and dreams, rushed into print and then disappearing into smoke. In the first catalogue, for example, the authors describe the crucial Table 113 as omitted just a few lines before it appears (von Grüber and Rüdin 1911a, 73). The pages instance hemophilia, congenital night blindness, and brachydactyly (shortened fingers) as known to be inherited independently and to segregate (mendeln), and indeed to be governed by a single genetic unit (Erbeinheit) or gene (Gene). The catalogue next refers back to "Table 112 Dahl's case on deaf-mutism," here described displaying a remarkable, simultaneous appearance of deaf-mutism and insanity in distant relatives in the fifth generation. The crucial point here is that the third and fourth generations were "practically free" of these conditions. More mistakes: 112, though from Dahl, was a different table, also copied from Pearson's Treasury. It showed no such eruption of hereditary illness. Table 113, they now declare, referring to the important table they claimed earlier to have omitted, "is entirely similar." But their topic here was degeneration, whereas Table 113 concerned Mendelism.

They come finally to the most astonishing result of all, the reconciliation of Mendel and Morel. The catalogue text veers back to speculate that Dahl's kinship table of deaf-mutism might supply a concrete instance of hereditary degeneration. In the next line they tried out a fusion of theories, Mendelism and degeneration. "Supposing the information (Angaben) in the kinship tables is complete in this respect, it gives the impression that an abnormal gene or an abnormal combination of genes from the shared heritage of the progenitors has at last attained so great a 
degree of degeneration that manifest derangements can occur." The degenerative force, they were suggesting, must have been intensified by family relationships and shared heredity - that is, cousin marriages. What else could explain the simultaneous appearance of a new irregularity in distinct lines of this kin group (von Grüber and Rüdin 1911a, 71-77, quotes 76-77)?

So many inconsistencies seem to reflect a momentary but irrepressible excitement regarding a putative demonstration from Dahl's data of Morel-style degeneration. In the "enlarged and completed" edition issued later the same year, the mistakes in the identification and numbering of tables were rectified. Rüdin, the psychiatrist, who presumably was responsible for this material, hints now at doubts as to the evidence for Morel-type degeneration by inserting a question mark: "Supposing the information... is complete (?)" Complete information on generations long dead may be depicted as a tree, but it does not grow on trees. Both editions, however, include an example of polydactyly (extra finger or toes) as an instance of the intensification of heredity, a tendency that Dahl, too, had endorsed. Certainly the authors did not rule out degeneration. This passage concludes by calling for more information (or data), that is more family trees of inherited illness (von Grüber and Rüdin 1911b, 75, 78, 81).

The investigation of madness and heredity was, by 1859, a recognized and even exemplary focus of data production. The hope that this data could be consolidated into databases of ever greater scale, to be analyzed in offices and exhibited in museums, burned brightly in those years, as it does in our own. But the detachment of data from the concrete conditions of its production is always risky. Data, as it moves, is most often thinned, and what is thinned is necessarily transformed.

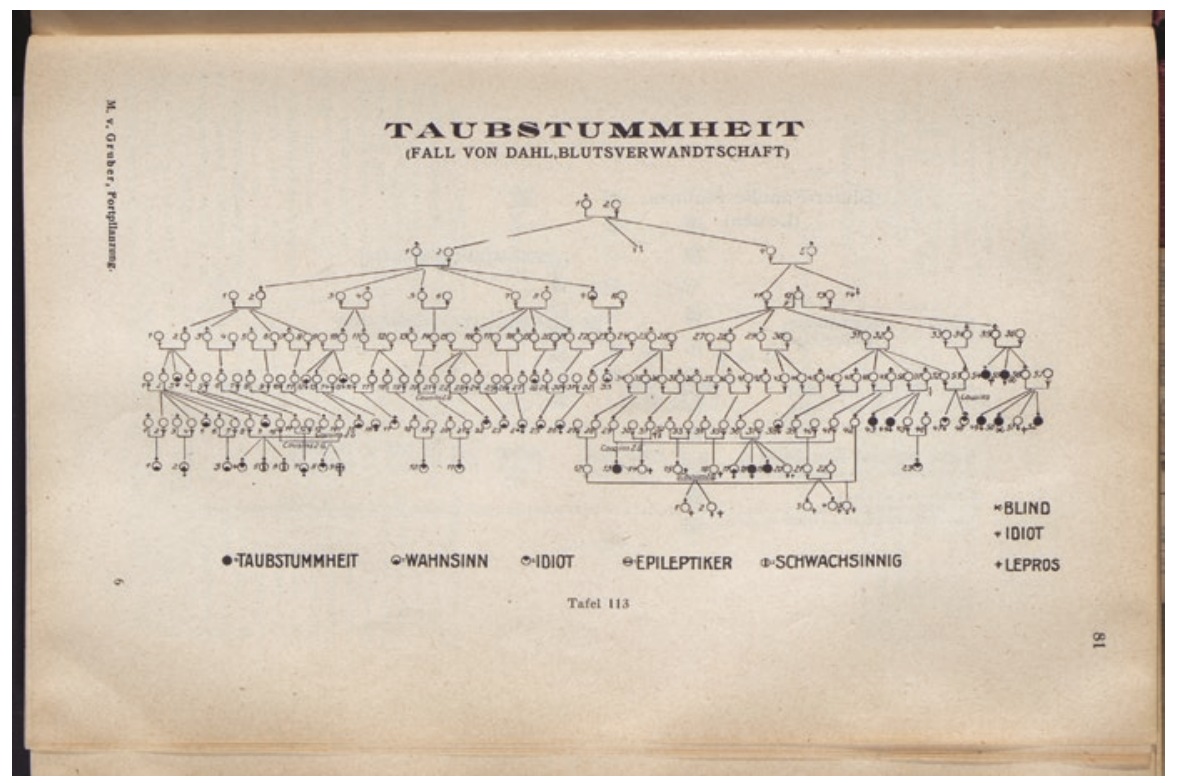




\section{References}

Dahl, Ludvig. 1859. Bidrag til Kundskab om de Sindssyge i Norge. Christiania: Det Steenske Bogtrykkeri.

Ireland, William W. 1877. Idiocy and Imbecility. London: J \& A Churchill.

Legrand du Saulle, Henri. 1873. La folie héréditaire. Paris: Adrien Delahaye.

Nikolow, Sybilla. 2001. Der statistische Blick auf Krankheit und Gesundheit. In Infografiken, Medien, Normalisierung: Zur Kartografie politisch-sozialer Landschaften, ed. Ute Gehrheit, Jürgen Link, and Ernst Schulte-Holtey, 223-241. Heidelberg: Synchron Wiss.-Verl. der Autoren.

Pearson, Karl, ed. 1912. Treasury of Human Inheritance, Vol. 1. London: Cambridge University Press, plate 10; this section was first printed in 1909.

Porter, Theodore M. 2004. Karl Pearson: The Scientific Life in a Statistical Age. Princeton: Princeton University Press.

2018. Genetics in the Madhouse: The Unknown History of Human Heredity. Princeton: Princeton University Press.

von dem Busch, Gerhard. 1861. Review of Dahl, Bidrag. Allgemeine Zeitschrift für Psychiatrie 18: 474-518.

von Grüber, Max, and Ernst Rüdin, eds. 1911a. Fortpflanzung, Vererbung, Rassenhygiene: Katalog der Gruppe Rasenhygiene der Internationalen Hygiene-Ausstellung, 1st ed. Munich: J. F. Lehmanns Verlag.

- eds., 1911b. Fortpflanzung, Vererbung, Rassenhygiene: Illustrierter Fuhrer durch die Gruppe Rasenhygiene der Internationalen Hygiene-Ausstellung, zweite ergänzte und verbesserte Auflage. Munich: J. F. Lehmanns Verlag.

Theodore M. Porter is Distinguished Professor of History at the University of California, Los Angeles. Much of his research has involved the history of statistics, quantification, calculation and data, often in relation to the human sciences. His most recent book, Genetics in the Madhouse: The Unknown History of Human Heredity, appeared in Princeton University Press in 2018. His other books include Karl Pearson: The Scientific Life in a Statistical Age (Princeton University Press, 2004), Trust in Numbers: The Pursuit of Objectivity in Science and Public Life (Princeton University Press, 1995) and The Rise of Statistical Thinking (Princeton University Press, 1986). He also credited with Dorothy Ross The Cambridge History of Science, Volume 7: Modern Social Sciences (Cambridge University Press, 2003).

Open Access This chapter is licensed under the terms of the Creative Commons Attribution 4.0 International License (http://creativecommons.org/licenses/by/4.0/), which permits use, sharing, adaptation, distribution and reproduction in any medium or format, as long as you give appropriate credit to the original author(s) and the source, provide a link to the Creative Commons license and indicate if changes were made.

The images or other third party material in this chapter are included in the chapter's Creative Commons license, unless indicated otherwise in a credit line to the material. If material is not included in the chapter's Creative Commons license and your intended use is not permitted by statutory regulation or exceeds the permitted use, you will need to obtain permission directly from the copyright holder.

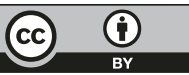

